\title{
Rare renal neoplasms in Salmo gairdneri exposed to MNNG (N-methyl-N'-nitro-N- nitrosoguanidine)
}

\author{
Brian C. Lee*, Jerry D. Hendricks**, George S. Bailey \\ Department of Food Science and Technology, Oregon State University, Corvallis, Oregon 97331-6602, USA
}

\begin{abstract}
N-methyl-N'-nitro-N-nitrosoguanidine (MNNG) is a potent liver, stomach, kidney, and swimbladder carcinogen in rainbow trout Salmo gairdneri. Histopathological examination of tissues from trout exposed as fry to $50 \mathrm{ppm}$ MNNG for 30 min revealed 2 types of neoplastic renal lesions not previously reported for this species. Renal cell carcinoma in the corpuscle of Stannius and renal cell, cystic, papillary adenoma of the mesonephric duct were diagnosed. Nephroblastoma and nephrocalcinotic lesions adjacent to the mesonephric duct adenoma suggested that occlusion of the duct could have been a contributing factor
\end{abstract}

\section{INTRODUCTION}

The rainbow trout has been a versatile and sensitive animal model in the study of chemical carcinogenesis (Hendricks et al. 1980, 1984, Hendricks 1982, Bailey et al. 1987). Inhibition, promotion, and enhancement of liver carcinogenicity by substances which may be present in the human diet, such as indoles, flavones, or chlorinated hydrocarbon pesticide residues, have been demonstrated in trout (Bailey et al. 1987, Dashwood et al. 1988, Fong et al. 1988, Nunez et al. 1988). Tissues in those studies are routinely subjected to histological examination to confirm gross observations and to determine the types of neoplastic responses.

Two renal tumor types, nephroblastoma and cystadenoma, have been reported for rainbow trout after exposure to $\mathrm{N}$-methyl- $\mathrm{N}^{\prime}$-nitro-N-nitrosoguanidine (MNNG). Nephroblastoma $(2.5$ and $7.5 \%$ incidence after $12 \mathrm{mo}$ ) was produced after embryonic exposures to static solutions of 30 or $100 \mathrm{ppm}$, respectively, for $1 \mathrm{~h}$ (Hendricks et al. 1980a). Intragastric administration of $120 \mathrm{mg} \mathrm{kg}^{-1}$ body weight followed $2 \mathrm{wk}$ later by a 240 $\mathrm{mg} \mathrm{kg} \mathrm{kg}^{-1}$ dose (Kimura et al. 1976) also produced an unspecified incidence of nephroblastoma. Exposure of

- Present address: Health Sciences Directorate, U.S. Consumer Product Safety Commission, Washington, D.C. 20207, USA.

- Adressee for reprint requests trout fry, 8 wk post swimup, to a static aqueous solution of $50 \mathrm{ppm}$ MNNG for $30 \mathrm{~min}$ produced a $35 \%$ incidence of nephroblastoma after 1 yr (unpubl. data, this laboratory). Cystadenoma (40\% incidence after $32 \mathrm{mo}$ ) was found in addition to nephroblastoma after embryonic exposure to 10 ppm for $24 \mathrm{~h}$ (Kimura et al. 1981). Other carcinogens, such as dimethylnitrosamine (Ashley 1970), methylazoxymethanol acetate (unpubl. data, this laboratory), and 7,12-dimethylbenz(a)anthracene (unpubl. data, this laboratory), can also produce nephroblastoma in the trout.

Experimentally-induced renal cell adenomas and carcinomas have never been reported in rainbow trout, and no neoplasm of any origin has ever been reported in the corpuscle of Stannius of any fish. The 2 rare renal neoplasms reported here will serve to alert experimental pathologists to these possibilities during examination of carcinogen-exposed fish.

\section{MATERIALS AND METHODS}

Groups of ca 120 Shasta strain rainbow trout Salmo gairdneri were fed the semipurified Oregon Test Diet (Sinnhuber et al. 1977), containing known or suspected modulators of carcinogenicity, for $6 \mathrm{wk}$ from swimup as part of an investigation into anti-carcinogenic chemicals. The group including Fish A received $2000 \mathrm{ppm}$ indole-3-carbinol in its diet (Sigma Chemical Co., St. 
Louls, MO, USA) (Nixon et al. 1984) Fish B, C, and D* were in a group fed $10 \%$ soy-based textured vegetable protein (Ralston Purina, St. Louls) substituted for the equivalent amount of casein in the diet

The fry were exposed to $50 \mathrm{ppm}$ MNNG (Sigma) for $30 \mathrm{mun}$, and raised on control Oregon Test Diet in tanks suppled with $14^{\circ} \mathrm{C}$ well water at the Food Toxicology and Nutntion Laboratory of Oregon State University Control fish were fed control diet and were sham exposed.

At age $12 \mathrm{mo}$, the fish were necropsied. Tissues were sampled, fixed in Boun's solution, conventionally pro-

\footnotetext{
- Fish identity nos. $A=E I 109 \# 38 . B=E I 111 \# 42, C=$
} EI112\#12. D = EI112\#38 cessed to paraffin sections, and stained with hematoxylin and eosin (H\&E), or when necessary, McManus periodic acıd-Schiff and hematoxylin (PAS \& $\mathrm{H}$ ) (Humason 1972). Distances between histological features were measured using a microscope ocular optical micrometer. Cases described in this report were the only ones of their types among 461 MNNG-treated and 120 control fish.

\section{RESULTS}

One corpuscle of Stannius in Fish A was infiltrated by moderately basophilic renal tubules of simple columnar epitheluum (Fig. 1). Brush borders were not

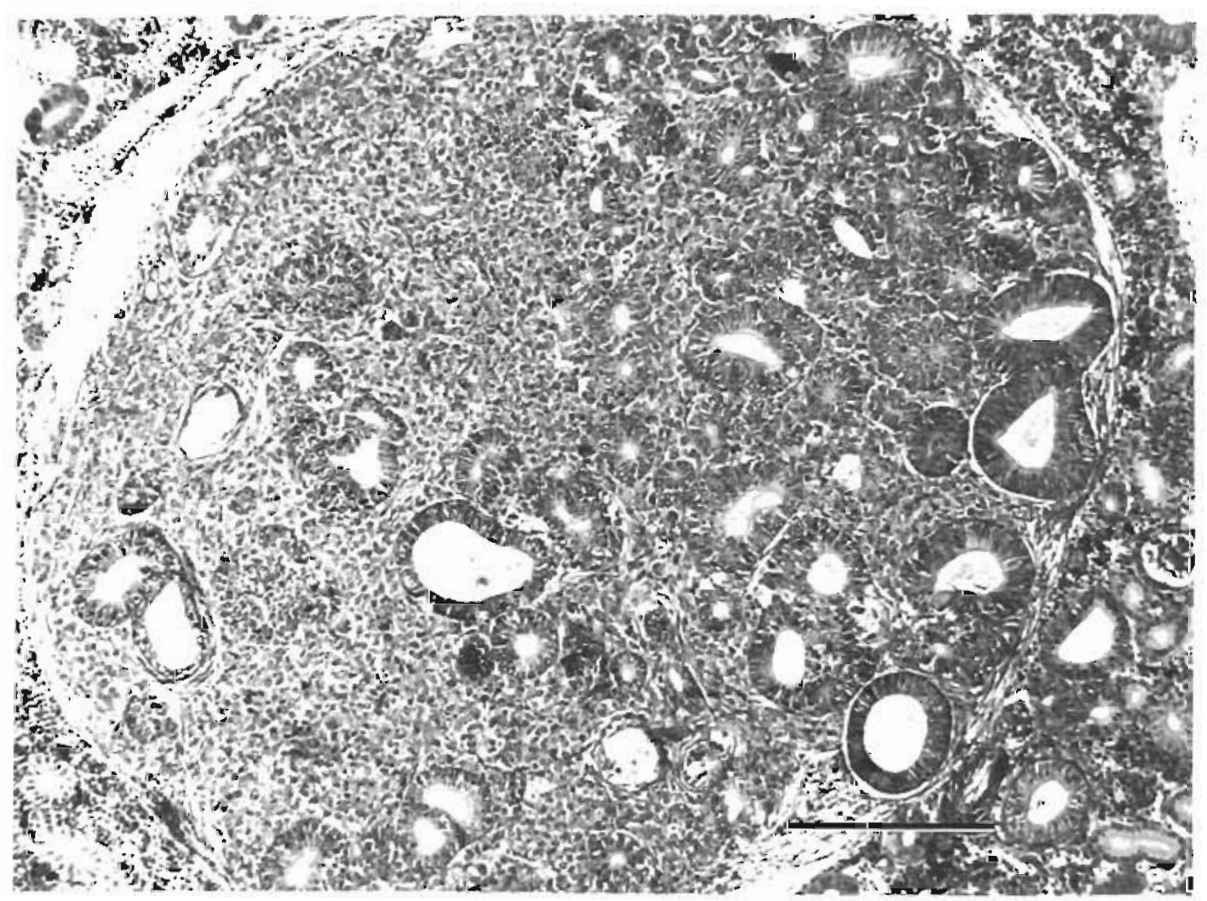

Fig. 1. Salmo gairdneri. Corpuscle of Stannius infiltrated with proliferating moderately basophilic renal tubules of columnar epithelium. Fish A. H \& E; $107 x$ Bar $=200 \mu \mathrm{m}$

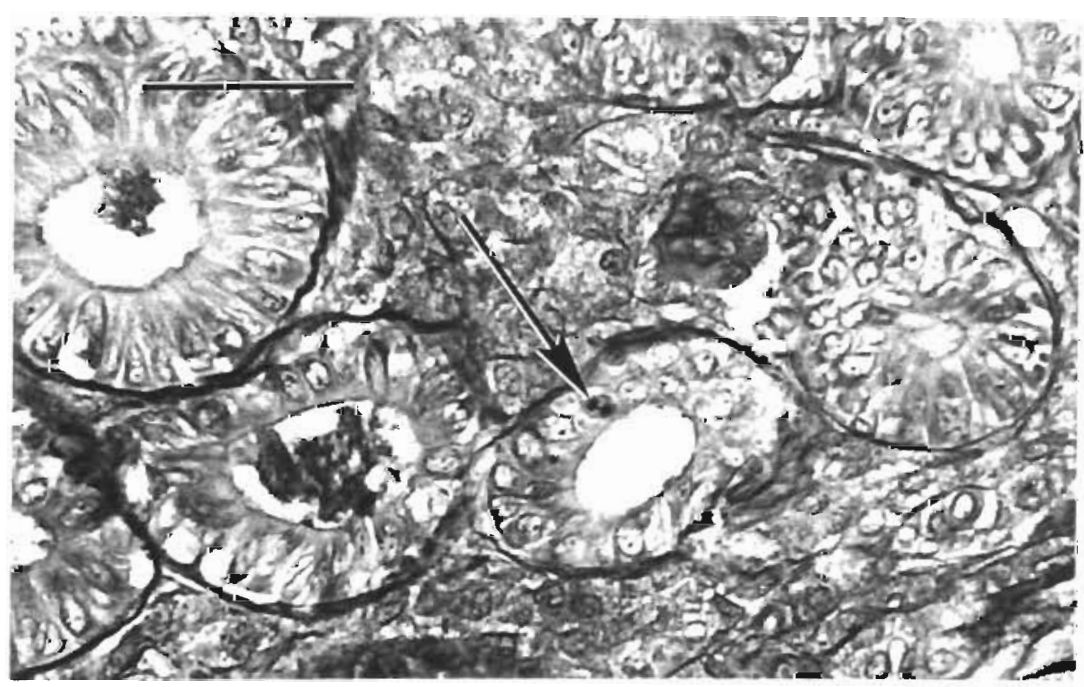

Fig 2. Salmo gairdneri. Mitotic figure (arrow in renal tubule cell in corpuscle of Stannius. Basal laminas are PAS + . Debris in lumens is due to nephrocalcinosis. PAS \& $\mathrm{H} ; 432 \times . \mathrm{Bar}=50 \mu \mathrm{m}$ 
present and tubules had either distal tubule or collecting duct features. No point of penetration of the tubules through the capsule of the corpuscle was located in the 6 semi-serial sections examined. Debris occasionally present within the lumens of the tubules was associated with the nephrocalcinosis that was occasionally observed in MNNG-treated fish throughout the study. Few mitotic figures (Fig. 2) were found in the tubule epithelial cells, indicating the proliferation rate was not unusually rapid. Granular and agranular cells of the corpuscle (Krishnamurthy \& Bern 1969) were normal and stained respectively PAS+ and PAS- (Figs. 2 and 3). A PAS+ reaction was elicited along the luminal border of a few of the renal epithelial cells within the corpuscle (Fig. 3), a characteristic of fully differentiated collecting and mesonephric duct cells (Bulger \& Trump 1968). Other corpuscles of Stannius in the same and adjacent kidney had normal cellular morphology and arrangement as described by Yasutake \& Wales (1983).

One region of a mesonephric duct in each of Fish $C$ and D became widely dilated (Fig. 4a,b). In these regions, the simple tall columnar epithelium became basophilic and occasionally stratified. The basophilic layer of rapidly proliferating epithelial cells projected into the lumen, forming highly basophilic cystic papillary structures of anaplastic cells. Nucleoli were darkly prominent and many mitotic figures were found (Fig 5). Basal laminas of the mesonephric ducts remained intact although the neoplastic cells at the base of one stalk compressed the underlying connective tissue (Fig. 5).

The shortest distance from the nearest affected por- tion of the mesonephric duct to a cystadenoma in Fish $\mathrm{C}$ was $1.38 \mathrm{~mm}$. However, a nephrocalcinotic lesion was in apposition to the duct. In Fish D, a nephroblastoma was $0.14 \mathrm{~mm}$ from the duct. Increased nephrocalcinosis was seen in the soy fed groups, but the lesions were not counted since the study was focused on assessing neoplastic responses.

Nephroblastoma has not been known to successfully metastasize in fish, but the first case of a nephroblastoma embolus at this lab was seen in Fish B (Fig. 6). The darkly basophilic embolus contained blastemal and glomeruloid features and was deficient in hemopoietic tissue as is typical of nephroblastoma in fish. The tumor of origin had surrounded and invaded the vessel wall where the embolus was found (Fig. 6).

Kidneys in the control fish were normal.

\section{DISCUSSION}

\section{Corpuscle of Stannius}

Corpuscles of Stannius are found only in teleosts but are functionally, histochemically, and immunologically similar to the parathyroid glands of higher vertebrates (Lopez et al. 1984). Neoplastic events within the corpuscle have never been previously reported, and the 2 parenchymal cell types (granular and agranular) were normal in Fish A. However, the proximity of other renal components may place the corpuscles at risk of neoplastic invasion, except in fish with remotely located corpuscles, such as charal Chirostoma jordani and

Fig. 3. Salmo gairdneri. A few cells of the tubules in the corpuscle of Stannius were sufficiently differentiated to become PAS+ along the luminal border (arrow). Granular and agranular cells of the corpuscle were respectively PAS + and PAS - . PAS \& $\mathrm{H} ; 432 \times$ Bar $=$ $50 \mathrm{~mm}$

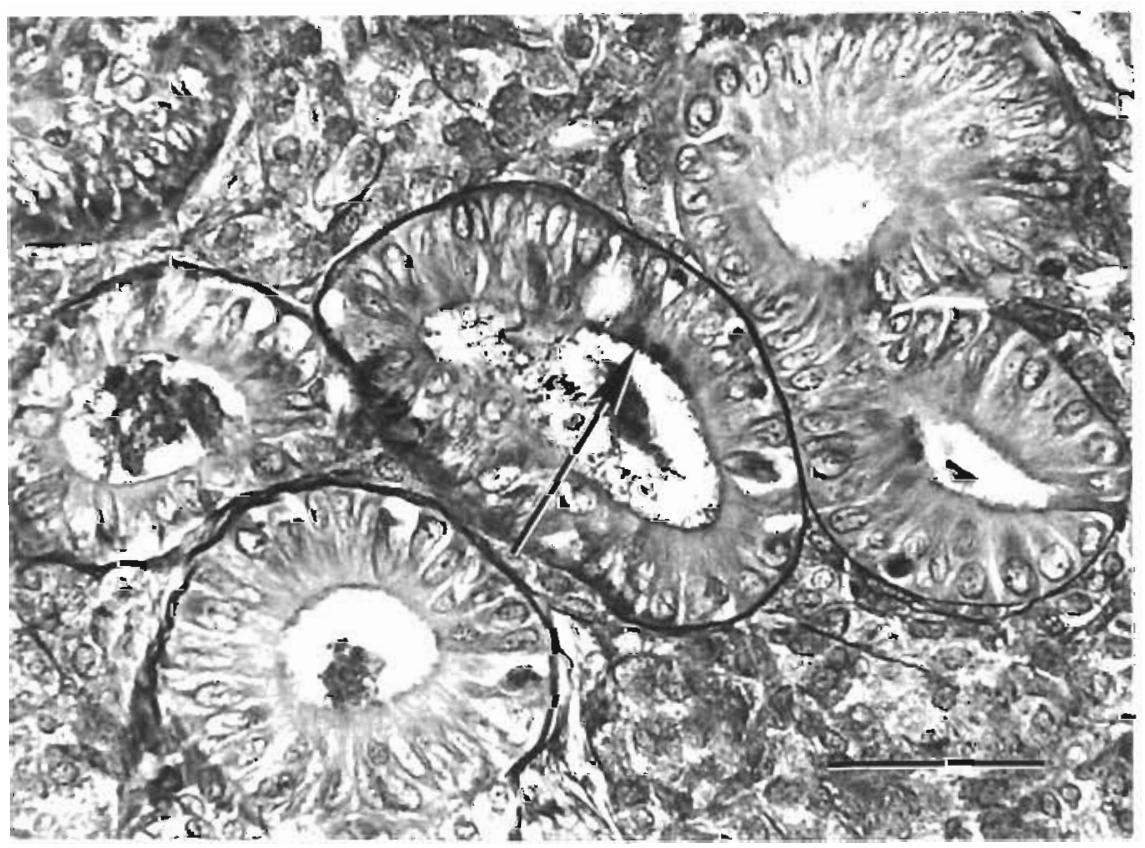



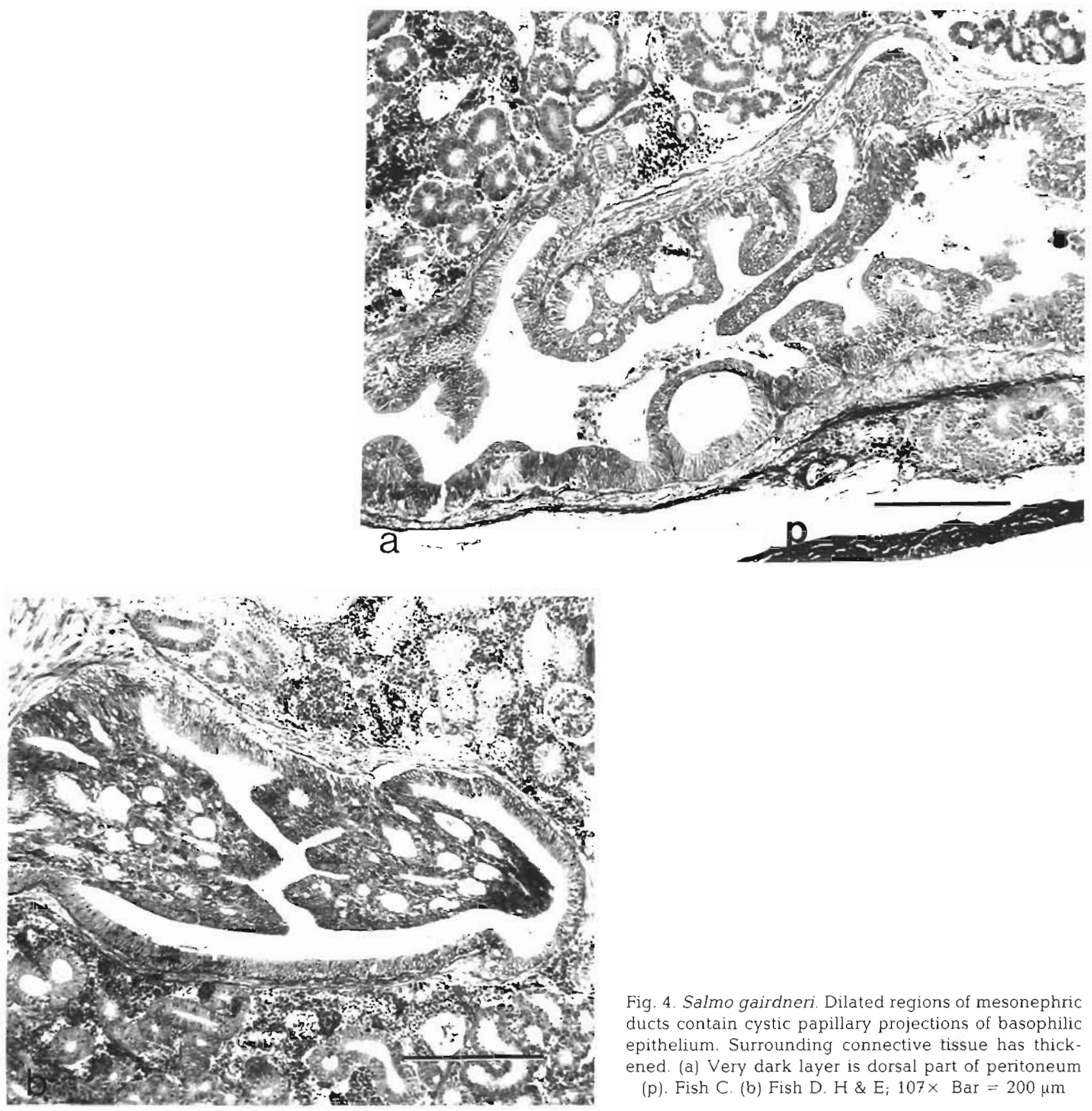

Fig. 4. Salmo gairdneri. Dilated regions of mesonephric ducts contain cystic papillary projections of basophilic epithelium. Surrounding connective tissue has thickened. (a) Very dark layer is dorsal part of peritoneum

(p). Fish C. (b) Fish D. H \& E; $107 \times$ Bar $=200 \mu \mathrm{m}$

Mexican whitefish Chirostoma estor (Hernandez \& Tolosa 1983).

Since the tubules have characteristics most like distal or collecting duct segments (Figs. 1 and 2) of the normal fish nephron (Bulger \& Trump 1968, Anderson \& Loewen 1975, Yasutake \& Wales 1983), it is likely the neoplasm originated from a morphologically similar region. The presence of renal tubules within the corpuscle of Stannius is clearly a departure from normal structure, as described by Yasutake \& Wales (1983), and is presumed to be the result of invasion. Although the primary neoplasm was not observed, this lesion must be considered a renal cell carcinoma, resulting from direct invasion or metastasis to the corpuscle of Stannius.

Modulation of renal carcinogenesis by pre-initiation indole-3-carbinol treatment has never been demonstrated, although dietary indole-3-carbinol can inhibit or enhance liver carcinogenesis in trout, depending on the sequence of exposures to modulator and carcinogen (Nixon et al. 1984, Bailey et al. 1987, Fong et al. 1988). Since this is the first case report of renal carcinoma in the corpuscle of Stannius, it is not possible to determine whether the indole-3-carbinol diet of Fish $A$ influenced the development of this lesion. 
Fig. 5. Salmo gairdneri. Tall columnar basophilic epithelium of the affected areas of the mesonephric duct is pseudostratified. Neoplastic cells (c) at the base of the stalk compress the surrounding connective tissue but have not advanced beyond the basal lamina. Papillary cells are anaplastic and highly basophilic. Many mitotic figures (arrows) are present and nucleoli are prominent. Fish D. $\mathrm{H} \& \mathrm{E}_{;} 432 \times$. Bar $=$ $50 \mu \mathrm{m}$

Fig. 6. Salmo gairdneri. Nephroblastoma embolus in a blood vessel has glomeruloid and blastemal structures. Primary tumor has surrounded and invaded the vessel. Fish $B$. $\mathrm{H} \& \mathrm{E} ; 107 \times \mathrm{Bar}=200 \mu \mathrm{m}$
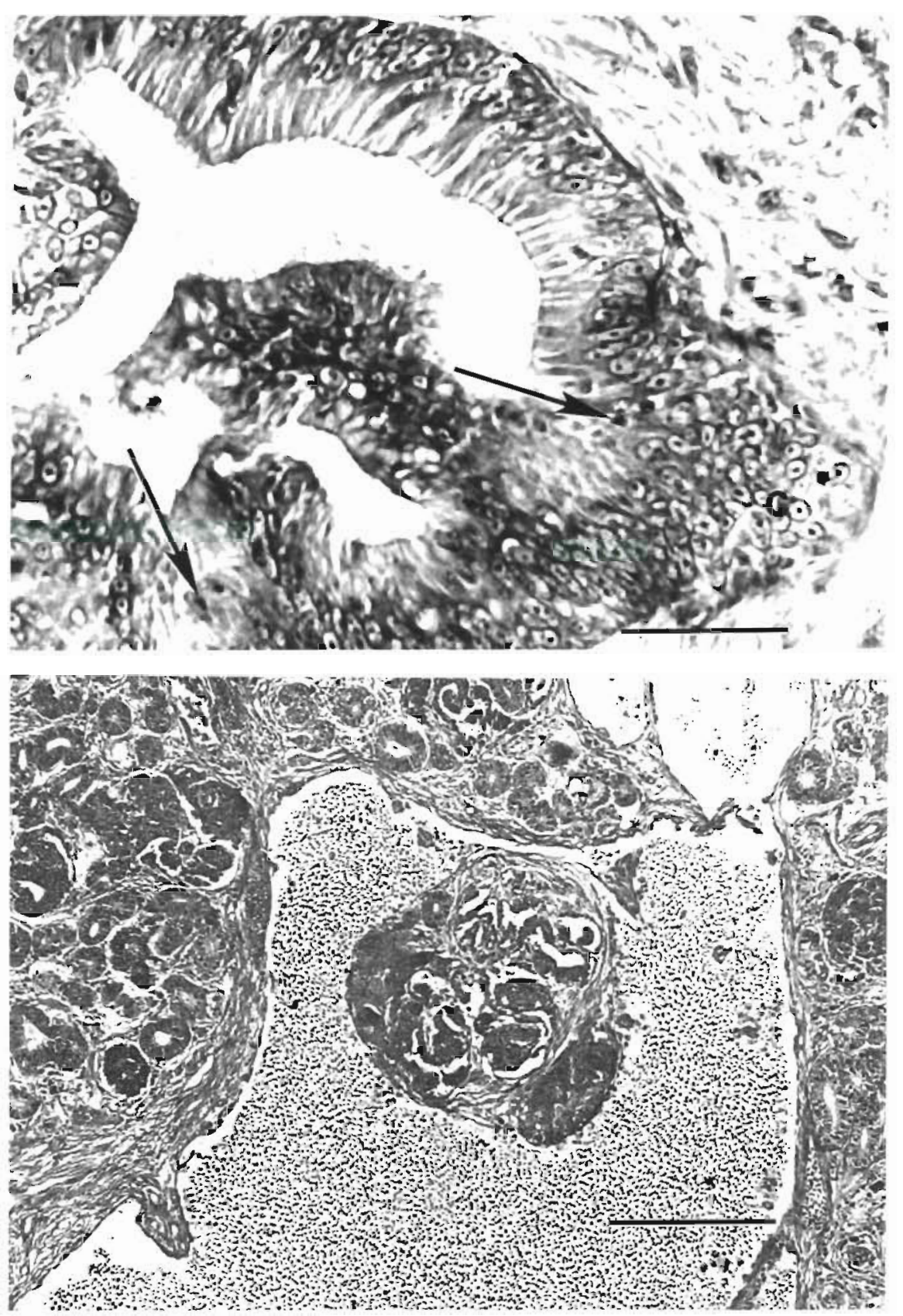

\section{Mesonephric duct}

Few cases of renal tubule-derived neoplasms have been reported for fish. Schmey (1911), according to Schlumberger \& Lucke (1948), discovered a cystic adenocarcinoma in a 3-yr-old eel Anguilla anguilla. An adenoma was found in a catfish Ameiurus nebulosus by Schlumberger \& Lucke (1948). Acinar arrangement and papillary projections into cystic spaces were noted. The histology of a papilliferous cystadenoma found in chinook salmon Oncorhynchus tshawytscha Walbaum from the Columbia River suggested the tumor had arisen from the mesonephric duct epithelium (Meyers \& Hendricks 1983). Hawkins et al. (in press) have observed a papillary renal adenocarcinoma in a guppy Poecilia reticulata exposed to the polycyclic aromatic hydrocarbon carcinogen, 7,12-dimethylbenz(a)anthracene

The mesonephric duct was the site of renal epithelial tumors in Fish C and D. The lesions exhibited highly neoplastic characteristics of basophilia, anaplasia, 
rapid proliferation, and papillary growth (Figs. 4a, b and 5). The cells were contained by the basal lamina, so the lesions can not be categorized as adenocarcinoma A diagnosis of cystic papillary adenoma of the mesonephric duct is warranted. Considering the 'aggressiveness' of the cells, carcinoma in situ would be an appropriate alternative description to adenoma.

\section{Coincident neoplasms}

It is highly unlikely that the coincident neoplasms, i.e. cystadenoma and nephroblastoma, were the origins of the rare renal neoplasms described in this report. Cystadenoma consists of widely distended tubulederived structures of normally staining simple epithelium and lacks invasiveness (Kimura 1976). Metastasis of nephroblastoma in fish has never been reported, although the analogous tumor is transplantable in rats (Hard \& Noble 1981) and can metastasize in the cow, dog, hamster, macaque, and rabbit (reviewed by Hard 1984) as well as in humans (Borg et al. 1987). The finding of a nephroblastoma embolus in a rainbow trout (Fig. 6) indicates that at least the potential for metastasis exists. However, the carcinoma of the corpuscle of Stannius and the renal cell papillary adenomas of the mesonephric ducts possessed none of the features typical of nephroblastoma, such as glomeruloid structures, blastema, or deficiency of hemopoietic tissue (Ashley 1970, Hendricks et al. 1980a, Kimura et al. 1981).

The papillary adenomas occurred only in the group fed soy protein. Soy has not been previously reported to modulate renal neoplasia, although raw full-fat soy protein isolate has been shown to enhance the percent of pancreatic volume containing azaserine-induced acidophilic foci in rats (Roebuck et al. 1987). A regenerative stimulation of the mesonephric ductal. epithelium in response to the tissue destruction due to more frequent nephrocalcinotic lesions in the soy-fed fish was not supported. Those processes were localized at the level of the tubules so that destruction and regeneration were not observed in the ducts.

Physical impingement of expansive or occlusive lesions on the mesonephric duct could cause a proliferative/metaplastic stimulus, analogous to the response of obstructed ducts of the pancreas or salivary gland (Robbins 1974, Shalimov et al. 1981). In both cases of papillary adenoma, a nephroblastoma or nephrocalcinotic lesion was sufficiently close to compress the duct. Although no blockages or occlusions were found, it was not possible to observe the entire ducts as they passed through the affected regions. Therefore, the role of coincident lesions in the promotion of the mesonephric duct adenoma remains speculative.
Acknowledgements. This report is \#8569 of the Oregeon Agricultural Experiment Station, Oregon State University. We thank Drs David E. Hinton and Mark Okihiro of the University of California at Davis for therr review of the lesions. We also express our gratitude to Dr Toshiko Morita for tissue processing services, and to John Casteel and Ted Will for diet preparation and animal care. This research was supported by U.S. Public Health Service grants ES 03850 and ES 00210 from the National Institute of Environmental Health Sciences, and CA 34732 and CA 44317 trom the National Cancer Institute.

\section{LITERATURE CITED}

Anderson, B. G., Loewen, R. D. (1975). Renal morphology of freshwater trout. Am. J. Anat. 143: 93-114

Ashley, L. M. (1970). Pathology of fish fed aflatoxins and other antimetabointes. In: Snieszko, S. F. (ed.) A symposium on diseases of fishes and shellfisches. American Fish. Soc. Special Publ. No. 5, Washington, D.C., p. 366-379

Bailey, G. S., Selivonchick, D. P., Hendricks, J. D. (1987). Initiation, promotion, and inhibition of carcinogenesis in rainbow trout. Envir. Hith Perspectives 71: 145-153

Borg, S. A., Rubin, P., DeWys, W D. (1987). Metastasis and disseminated disease. In: Rubin, P. (ed.) Clinical oncology, a multidisciplinary approach, 6th edn. American Cancer Soc., New York, Chap. 31, p. 498-515

Bulger, R. E., Trump, B. F. (1968). Renal morphology of the English sole (Parophrys vetulus). Am. J. Anat. 123: 195-226

Dashwood, R. H., Arbogast, D. N., Fong, A. T., Hendricks, J. D., Bailey, G. S. (1988). Mechanisms of anti-carcinogenesis by indole-3-carbinol: detailed in vivo DNA binding doseresponse studies after dietary administration with aflatoxin $B_{1}$. Carcinogenesis 9: 427-432

Fong, A. T., Hendricks, J. D., Dashwood, R. H., Van Winkle, S., Lee, B. C., Bailey, G. S. (1988). Modulation of diethylnitrosamine-induced hepatocarcinogenesis and $\mathrm{O}^{6}$-ethylguanine formation in rainbow trout by indole-3-carbinol, B-naphthoflavone, and Aroclor 1254. Toxic. appl. Pharmac. 96: 93-100

Hard, G. C. (1984). Comparative oncology I. Nephroblastoma in laboratory mammals. II. Nephroblastoma in domesticated and wild animals. In: Pochedly, C., Baum, E. S. (eds.) Wilms tumor clinical and biological manifestations. Elsevier, New York, p. 147-167, 169-214

Hard, G. C., Noble, R. L. (1981). Occurrence, transplantation, and histologic characteristics of nephroblastoma in the $\mathrm{Nb}$ hooded rat. Investig. Urol. 18: 371-376

Hawkins, W. E., Walker, W. W., Lytle, J. S., Lytle, T. F., Overstreet, R. M. (in press). Carcinogenic effects of 7,12dimethylbenz[a]anthracene on the guppy (Poecilia reticulata). Aquat. Toxic

Hendricks, J. D. (1982). Chemical carcinogenesis in fish. In: Weber, L. J. (ed.) Aquatic toxicology, Vol. 1. Raven Press, New York, p. 149-211

Hendricks, J. D., Meyers, T R., Casteel, J. L., Nixon, J. E., Loveland, P. M., Bailey, G. S. (1984). Rainbow trout embryos: advantages and limitations for carcinogenesis research. Natl Cancer Inst., Monogr 65: 129-137

Hendricks, J. D., Scanlan, R. A., Williams, J. L., Sinnhuber, R O., Grieco, M. P. (1980a). Carcinogenicity of $N$-methyl- $N^{\prime}=$ nitro- $\mathrm{N}$-nitrosoguanidine to the liver and kidney of rainbow trout. (Salmo gairdneri) exposed as embryos. J. nati Cancer Inst. 64: 1511-1519

Hendricks, J. D., Wales, J. H., Sinnhuber, R. O., Nixon, J. E., Loveland, P. M. Scanlan, R. A. (1980b). Rainbow trout 
(Salmo gairdneri) embryos: a sensituve animal for experimental carcinogenesis. Fed. Proc. 39: 2333-2339

Hernandez, R. G., Tolosa, J. S. (1983). Caracteristicas histologicas e histoquimicas de los corpusculos de Stannius en Chirostoma jordan y Chirostoma estor. Veterinaria (Mexico City) 14: 86-92

Humason, G. L. (1972). Animal tissue techniques, 3rd edn. W. H. Freeman \& Co, San Francisco, p. 325-328

Kimura, I., Kitatori, H., Yoshizaki, K., Tayama, K., Ito, M., Yamada, S. (1981). Development of tumor in rainbow trout following embryonic exposure to $\mathrm{N}$-nitroso compounds. In: Dawe, C. J., Harshbarger, J C., Kondo, S., Sugimura, T., Takayama, S. (eds.) Phyletic approaches to cancer Japan Scientific Soc. Press, Tokyo, p. 241-252

Kimura, I., Miyake, T., Yoshizaki, K. (1976). Induction of tumors of the stomach, of the liver and of the kidney in rainbow trout by intrastomach administration of N-methylN-nitroso-N'-nitrosoguanidine (MNNG). Proc. Jpn. Cancer Assoc. 35: 16, abstract \#15

Krishnamurthy, V G., Bern, H. A. (1969). Correlative histologic study of the curpuscles of Stannius and the juxtaglomerular cells of teleost fishes. Gen. Comp. Endocrinol. 13: 313-335

Lopez, E., Tisserand-Jochem, E.-M., Vidal, B., Milet, C., Lallier, F., Macintyre, I. (1984). Les corpuscules de Stannius sont-ils les glandes parathyroides des Poissons teleosteens? Arguments ultrastructuraux, cytologiques et immunocytochimiques. C. r Séanc. Acad. natn. Sci., Paris Serie III 298: 359-364

Meyers, T. R., Hendricks, J. D. (1983). Histopathology of four spontaneous neoplasms in three species of salmonid fishes. J. Fish Dis. 6: 481-499
Nixon, J. E., Hendricks, J. D., Pawlowski, N. E., Pereira, C. B., Sinnhuber, R. O., Bailey, G. S. (1984). Inhibition of aflatoxin $B_{1}$ carcinogenesis in rainbow trout by flavone and indole compounds. Carcinogenesis 5: 615-619

Nunez, O., Hendricks, J. D., Bailey, G. S. (1988). Enhancement of aflatoxin $B_{1}$ and MNNG hepatocarcinogenesis in rainbow trout (Salmo gairdneri) by $17 \mathrm{~B}$ estradiol and other organic chemicals. Dis. aquat. Org. 5: (3): 185-196

Robbins, S. L. (1974). Metaplasia. In: Robbins, S. L. (ed.) Pathologic basis of disease. W B. Saunders Co., Philadelphia, p. 17-18

Roebuck, B. D., Kaplita, P. V., Edwards, B. R., Praissman, M. (1987). Effects of dietary fats and soybean protein on azaserine-induced pancreatic carcinogenesis and plasma cholecystokinin in the rat. Cancer Res. 47: 1333-1338

Schlumberger, H. G., Lucke, B. (1948). Tumors of fishes, amphibians, and reptiles. Cancer Res. 8: 657-754

Schmey, M. (1911), Über Neubildungen Fischen. Frankf. Z. Pathol. 6: 230-253

Shalimov, A. A., Medvetskii, E. B., Keisevich, L. V (1981). Mechanisms of metaplasia of the duct epithelium of organs of the pancreaticobiliary system. Bull. exp. Biol. Med. (USSR) 92: 991-993

Sinnhuber, R. O., Hendricks, J. D., Wales, J. H., Putnam, G. B. (1977). Neoplasms in rainbow trout, a sensitive animal model for environmental carcinogenesis. Ann. N.Y Acad. Sci. 298: 389-408

Yasutake, W T., Wales, J. H. (1983). Endocrine system. In Microscopic anatomy of salmonids: an atlas. U.S. Dept. Interior, Fish and Wildlife Service Resource Publication 150, Washington, D.C., Chap. 13, p. 152-179 